\title{
Stiladzy - radziecki wariant pokolenia '52 i jego obraz w filmie Stiladzy Walerego Todorowskiego
}

Zarys treści: Stiladzy byli pierwszą subkulturą młodzieżową w Związku Radzieckim. Pojawili się w latach czterdziestych XX w. i przetrwali do początku lat sześćdziesiątych. Zaliczani są do tzw. pokolenia '52 - subkultur młodzieżowych zafascynowanych amerykańskim stylem życia. Temat stilagów powrócił w Rosji w związku z filmem Walerego Todorowskiego Stiladzy z 2008 r. $\mathrm{Na}$ jego kanwie toczyła się dyskusja o tej roli subkultury w ZSRR. Dla jednych stiladzy byli niemalże dysydentami, dla innych - zdegenerowaną młodzieżą.

Outline of content: The stilyagi were the first subculture in the Soviet Union, from the late 1940s to the early 1960s; they are regarded as part of the so-called "Generation '52". They were young people fascinated by American way of life. The topic of stilyagi subculture showed up again in Russia in connection with Valery Todorovsky's film Stilyagi of 2008. The film provoked a discussion about the role played by the stilyagi within the soviet state: for some they were almost dissidents, while for others - degenerated gilded youth.

Słowa kluczowe: lata pięćdziesiąte, ZSRR, życie codzienne, stiladzy, subkultura młodzieżowa, współczesne kino rosyjskie, kultura popularna współczesnej Rosji

Keywords: the 1950s, Soviet Union, daily life, stilyagi, youth subculture, contemporary Russian cinema, popular culture of modern Russia 


\section{Subkultura jako forma kontestacji systemu ${ }^{1}$}

Szeroko pojęty egalitaryzm pozostawał jednym z najważniejszych składników przekazu propagandowego kształtującego społeczeństwo radzieckie przez cały okres istnienia Związku Radzieckiego. Dotykał on nie tylko uniwersaliów: równości wobec prawa, sprawiedliwego podziału dóbr czy możliwości uczestnictwa w życiu publicznym bez względu na etniczność oraz usytuowanie zawodowe. Nie mniej znacząco podkreślano „standaryzację” obowiązującą we wszystkich wymiarach życia codziennego: obywatele radzieccy powinni byli ubierać się $\mathrm{w}$ jednakowym stylu, spożywać jednorakie posiłki, urządzać swoje miejsca zamieszkania w ten sam sposób, korzystać z jednakowej oferty rozrywek. Przejawy niezgodności stylu życia z obowiązującymi normami napiętnowano i w zdecydowanej większości surowo karano. Co właściwe dla systemów totalnych, również w ZSRR, istotnymi cechami charakterystycznymi przyjętej obyczajowości miały być: ascetyczna forma, skromność i utylitarność. I chociaż państwo radzieckie posiadało doprowadzone do perfekcji mechanizmy inwigilacji, również i tam pojawiły się grupy, które rzuciły wyzwanie zestandaryzowanej rzeczywistości.

Kontestacja rozumiana jako demonstracyjne, wręcz celowe i prowokacyjne naruszanie panujących norm, zachowywanie się dziwacznie (względem przyjętych obyczajów) i odmiennie od innych jednostek, ignorowanie akceptowanych reguł zachowania społecznego, połączone z zastępowaniem ich własnymi ekscentrycznymi zasadami ${ }^{2}$, doskonale opisuje postawę, którą wobec systemu przyjęli stiladzy - członkowie pierwszej radzieckiej subkultury. Zaistniały w latach pięćdziesiątych XX w. i oparty na fascynacji kulturą amerykańską ruch stilagów nie stworzył bowiem jakiegokolwiek programu politycznego, nie generował haseł

\footnotetext{
${ }^{1} \mathrm{~W}$ odniesieniu do stilagów i innych wspominanych w tym tekście grup młodzieżowych będę używała wymiennie terminu „subkultura” bądź „młodzieżowy ruch kulturowy”. Za przyjęciem pierwszego określenia przemawia argumentacja socjologów Mirosława Pęczaka i Mariana Filipiaka, proponujących zastosowanie pojęcia „subkultura” na nazwanie różnych ruchów kulturowych, których istotą (w przeciwieństwie do kontrkultury oraz kultury alternatywnej) jest niejednoznaczny stosunek do kultury dominującej. Zob. M. Pęczak, Mały słownik subkultur młodzieżowych, Warszawa 1992, s. 4; M. Filipiak, Od subkultury do kultury alternatywnej. Wprowadzenie do subkultur młodzieżowych, Lublin 1999, s. 16. Termin „młodzieżowy ruch kulturowy” został wyprowadzony przez Viktora Tarnavskiego na określenie bardzo zróżnicowanych ugrupowań młodzieżowych powstałych u schyłku i po upadku ZSRR. Tarnavskyi proponuje, aby za podstawowy element wspólny tych ruchów uznać regularne specyficzne praktyki grupowe, takie jak m.in.: oryginalne formy ekspresji twórczej (np. muzyka, taniec), specyficzny system semantyczny (wygląd zewnętrzny, posiadanie przedmiotów symbolicznych oraz własnych znaków rozpoznawczych), specyficzny sposób porozumiewania się (slang) oraz wspólne spędzanie czasu wolnego. Termin ten, w moim przekonaniu, można zaadoptować na określenie ugrupowań $\mathrm{z}$ lat trzydziestych, czterdziestych i pięćdziesiątych, które nie tyle występowały przeciwko kulturze dominującej, ile kontestowały ją za pomocą nienormatywnych dla niej praktyk. Zob. V. Tarnavskyi, Dzieci swoich czasów. Ruchy młodzieżowe w Rosji a zmiany kulturowe po upadku ZSRR, Warszawa 2007, s. 98.

2 T. Paleczny, Kontestacja. Formy buntu we współczesnym społeczeństwie, Kraków 1997, s. 8.
} 
nawołujących do reformy państwa radzieckiego, nie werbalizował nawet żadnych konkretnych postulatów. Uderzał $\mathrm{w}$ system nonszalanckim bojkotem radzieckiej obyczajowości poprzez ekstrawagancki ubiór, specyficzny slang i zamiłowanie do niepopularnych w ZSRR rozrywek. Stiladzy kontestowali otaczającą ich rzeczywistość, zachowując pełną obojętność wobec mobilizacji do budowy komunizmu. Mimo braku politycznej aktywności ostentacyjne czerpanie z najbardziej wrogich ideologii radzieckiej amerykańskich wzorców kulturowych ściągało na nich odium nie tylko zdeprawowanych odszczepieńców społecznych, ale i wrogów ojczyzny.

\section{Pokolenie '52}

Ruch radzieckich stilagów nie był odosobnionym fenomenem, lecz częścią ogólnoeuropejskiego zjawiska, tzw. pokolenia '52, czyli fali subkultur fascynujących się amerykańskim stylem życia ${ }^{3}$. Obok stilagów zaliczyć tu można francuskich zazous (realnie funkcjonujących w latach czterdziestych XX w.), brytyjskich teddy boys, rumuńskich malagambistów, czechosłowackich potàpka oraz polskich bikiniarzy. Wiele podobnych cech wykazywała też nieco wcześniejsza niemiecka subkultura młodzieżowa Swingkinder ${ }^{4}$. Wszystkie te ruchy replikowały specyficzny styl bycia wytworzony w środowisku czarnoskórej i latynoskiej mniejszości w Stanach Zjednoczonych w latach trzydziestych XX w. Styl ten charakteryzowały pasja do jazzu i jive’a, osobliwy żargon oraz niekonwencjonalny strój - zoot suit, którego podstawowym rekwizytem była długa, luźna, najczęściej jednorzędowa marynarka, $\mathrm{z}$ rozbudowanymi ramionami oraz zwężające się ku dołowi spodnie $\mathrm{z}$ wysoką talią. Nazwa zoot suit odnosiła się zarówno bezpośrednio do stroju, jak i do noszących go przedstawicieli subkultury, zwanych również zooters ${ }^{5}$. Obok luźnego garnituru ze stylem tym asocjowała się także fryzura DA (skrót od duck's ass - „kacza dupa"), która polegała na spiętrzeniu czuba nad czołem i zaczesywaniu wybrylantynowanych włosów po bokach tak, by tworzyły z tyłu niejako „kuper”. zootersów i powstały w ich kręgu język slangowy znacząco wpłynęly na środowisko amerykańskich muzyków jazzowych i stały się symbolem zmiany obyczajowej w wielu krajach na świecie.

\footnotetext{
${ }^{3}$ M. Chłopek, Bikiniarze. Pierwsza polska subkultura, Warszawa 2005, s. 38.

${ }^{4}$ Wymienione $\mathrm{w}$ tym miejscu subkultury należą do najlepiej rozpoznanych w polskiej literaturze naukowej. Zjawisko, o którym mowa, wystąpiło jednak również w Belgii, Austrii, Włoszech, Danii, Szwecji, a także w Australii, Nowej Zelandii i na Jamajce, ibidem, s. 58, 64, 72-76.

${ }^{5}$ Samo określenie zoot suit pochodzi najprawdopodobniej od zniekształconej formy angielskiego słowa suit oznaczającego garnitur, choć według innych interpretacji należy łączyć je z holenderskim zoet (słodki) bądź z bliżej nieokreślonym afrykańskim dialektem. Zob. T. Thorne, Mody, kulty, fascynacje. Słownik pojęć kultury postmodernistycznej, tłum. Z. Batko, Warszawa 1995, s. 404-405. Szerzej na temat zoot suit zob. M. Chłopek, op. cit., s. 39-47.

6 T. Thorne, op. cit., s. 66.
} 
Ruchy pokolenia ' 52 pojawiały się zarówno w krajach o totalitarnym i autorytarnym ustroju (Swingkinder w III Rzeszy ${ }^{7}$, zazous w okupowanej Francji ${ }^{8}$ ), jak i w liberalnych demokracjach $\mathrm{z}$ konserwatywnym podziałem klasowym (teddy boys w Wielkiej Brytanii ${ }^{9}$ ), wszędzie jednak charakteryzował je generalnie głęboki dystans wobec świata polityki oraz hedonistyczne podejście do życia. Ruchami młodzieżowymi, które zaadoptowały styl zoot suit w Europie Środkowo-Wschodniej, byli rumuńscy malagambiści (od Sergiu Malagamba - prawdopodobnie jednego z pierwszych rumuńskich zootersów), czechosłowaccy potàpka (potàpka, czyli kaczka - ze względu na kolorowy ubiór) i polscy bikiniarze (od krawatów z motywem atolu Bikini, na którym Amerykanie w latach 1946-1958 przeprowadzali próby $z$ bronią jądrową) $)^{10}$. Przedstawiciele tych subkultur promowali modę amerykańską oraz fascynację jazzem i swingiem w swoich krajach już w latach czterdziestych XX w., posługiwali się specyficznym slangiem na bazie angielszczyzny, włącznie $z$ nadawaniem imionom angielskiego brzmienia, spędzali dnie na „zdobywaniu” zachodniej odzieży i gadżetów oraz na ostentacyjnym, publicznym „nicnierobieniu”.

Poza strojem i stylem bycia ruchy pokolenia ' 52 łączył fakt, że zostały one potępione przez kultury oficjalne swoich państw oraz wyszydzane na łamach rządowej prasy. Z najsurowszymi represjami spotkała się młodzież w III Rzeszy, gdzie część Swingkinders trafiła do obozów koncentracyjnych ${ }^{11}$. We Francji represje wobec zazous (ataki na kawiarnie, przymusowe golenie głowy, zsyłki na prowincję do pracy na roli czy wreszcie do obozów pracy) nasiliły się po przystąpieniu Stanów Zjednoczonych do wojny ${ }^{12}$. We wszystkich krajach starano się też, aby wybryki chuligańskie i skandale, których dopuścili się członkowie opisanych subkultur lub ich radykalnych odłamów, rzutowały na obraz całego ruchu. W latach pięćdziesiątych XX w. zarówno w krajach Europy Środkowo-Wschodniej, jak i samym ZSRR najmniejszy przejaw zainteresowania kulturą amerykańską traktowano jako zagrożenie działalnością szpiegowską.

\section{Fenomen stilagów w ZSRR}

Stiladzy jako radziecki wariant pokolenia ' 52 stanowili jeden z niewątpliwie najciekawszych fenomenów czasów stalinowskich. Niezbyt liczne grupy fantazyjnie

\footnotetext{
7 R. Grunberger, Historia społeczna Trzeciej Rzeszy, tłum. W. Kalinowski, t. 2, Warszawa 1987, s. 133; A. Fedorowicz, Swing heil!, „Polityka” (21 IV 2015).

8 T. Szarota, Życie codzienne w stolicach okupowanej Europy. Szkice historyczne. Kronika wydarzeń, Warszawa 1995, s. 83-86, 116.

9 T. Thorne, op. cit., s. 362.

10 Temat bikiniarstwa jest szeroko opisany w pracy M. Chłopka, op. cit., s. 77-163.

11 A. Fedorowicz, op. cit.; R. Grunberger, op. cit., s. 133.

12 L. Portis, French Frenzies. A Social History of Pop Music in France, College Station 2004, s. 105.
} 
ubranej młodzieży pojawiły się w dużych miastach europejskiej części ZSRR: Leningradzie, Moskwie, Kijowie, Lwowie, a także Baku pod koniec lat czterdziestych. Przenikanie trendów modowych i obyczajowych z Europy Zachodniej do ZSRR było możliwe dzięki relacjom żołnierzy powracających $\mathrm{z}$ frontu oraz cywilów zesłanych na roboty do Niemiec, a także tłumaczeniom dzieł „antyfaszystowskich” autorów zachodnich, jak Erich Maria Remarque, Elsa Triolet, Ernest Hemingway czy Antoine de Saint-Exupéry, których twórczość dostarczała radzieckiemu czytelnikowi informacji o realiach życia na Zachodzie ${ }^{13}$. Podstawowym narzędziem ekspresji „odmienności” stilagów był ubiór, na który składały się: buty na grubej, jasnej podeszwie (tzw. buty na „kaszy mannie”), wąskie, przykrótkie spodnie (tzw. dudoczki), szerokie, kolorowe lub kraciaste marynarki, kolorowe krawaty z egzotycznymi motywami (małpy, palmy itp.), długie płaszcze i kapelusze ${ }^{14}$. $\mathrm{O}$ atrakcyjności stroju decydowały jak najbardziej kontrastujące ze sobą połączenia barw oraz dodatkowe elementy, takie jak fryzura DA, u kobiet zaś wyrazisty makijaż (co w sytuacji problemów z dostępnością kosmetyków kolorowych musiało oznaczać każdą formę makijażu).

Używana przez otoczenie nazwa „stiladzy” pochodzi od jednej z ważniejszych form aktywności tej subkultury, jaką był zakazany w ZSRR taniec typu boogie-woogie (być stilagą oznaczało tańczyć „stylem”) ${ }^{15}$. Nazwa ta została po raz pierwszy publicznie użyta w felietonie Dmitrija Bielajewa z 1949 r., opublikowanym na łamach oficjalnego satyrycznego czasopisma radzieckiego „Krokodił”. Sami stiladzy posługiwali się w stosunku do siebie pojęciami „czuwak/ czuwicha”, które rozszyfrowywali jako: „Человек Уважающий Высокую Американскую Культуру” („człowiek szanujący wysoką kulturę amerykańską” ${ }^{16}$. Autoironia wynikająca z tej nazwy dowodziła zdystansowanego wobec siebie stylu bycia, podczas gdy ich fascynacja kulturą Stanów Zjednoczonych była w pełni autentyczna. Najważniejszy wyraz owej fascynacji stanowiło zainteresowanie muzyką jazzową, którą w ZSRR

13 A. Matyukhina, W sowieckim Lwowie. Życie codzienne miasta w latach 1944-1990, Kraków 2000, s. 97.

14 V. Tarnavskyi, op. cit., s. 103.

15 Ibidem. Do połowy lat sześćdziesiątych w miejscach publicznych istniał zakaz tańczenia także tanga, fokstrota, charlestona i rock and rolla. Dozwolone były natomiast: walc, polka, krakowiak, mazurek i polonez. Zob. A. Matyukhina, op. cit., s. 31; Н. Шліхта, Історія радянсього суспільства. Курс лекцій, Харків 2015, s. 173.

16 Pochodzenie słowa „czuwak” nie zostało dotychczas naukowo zbadane, natomiast do dziś funkcjonuje ono w potocznym języku rosyjskim w znaczeniu: „chłopak”, „równy gość”. Jego wymowa jest bezdyskusyjnie pozytywna. Żeński odpowiednik „czuwicha” został zarejestrowany w złodziejskim żargonie z początku XX w. i za sprawą pochodzących z lat trzydziestych ustaleń radzieckiego filologa Aleksieja Barannikowa przypisywano mu etymologię cygańską. Obecnie jednak ustalenia te poddawane są krytyce. Zob. В.В. Шаповал, Цыганские элементы в русском воровском арго? (размышления над статьей акад. А.П. Баранникова 1931 г.), „Вопросы языкознания” (2007), № 5, s. 108-128, za: Philology.ru - Русский филологический портал, http://www.philology.ru/ linguistics2/shapoval-07c.htm (dostęp: 23.10.2018). 
postrzegano jako „produkt kultury burżuazyjnej” i - mimo braku prawnych zakazów - faktycznie zwalczano ${ }^{17}$. Pewne ustępstwa udawało się wszelako osiągać:

Танцплощадки были коммерческим предприятием - они приносили единственный доход директорам клубов, дворцов и доход директорам клубов, дворцов и домов культуры. А молодежь можно привлечь только запрещенным фокстротом. И руководители этих учреждений старались пробить разрешение у своего партийного начальства на как можно больший процент идеологически вредных танцев. Удавалось это далеко не всем ${ }^{18}$.

Obok tańca stiladzy zajmowali się zdobywaniem zachodnich ubrań, gadżetów, płyt i książek, co wymagało zawierania i pielęgnowania znajomości z tymi, którzy mieli możliwość wyjeżdżania za granicę, tj. dyplomatami, elitą artystyczną i sportową oraz „farcowszczikami” ${ }^{19}$. Ważne były także kontakty z handlującymi na czarnym rynku, krawcowymi, pracownikami portów oraz lokali przeznaczonych dla zagranicznych turystów. Spotkania stilagów odbywały się m.in. na tzw. chatach (tj. w mieszkaniach ich rodziców - nomenklatury partyjnej lub elity artystycznej), gdzie słuchano radia BBC, Głosu Ameryki, oglądano zachodnie filmy, tańczono oraz pito oryginalne trunki ${ }^{20}$. Innym rodzajem spotkań było ostentacyjne przechadzanie się w „stylowej odzieży” po głównej ulicy miasta, którą nazywano lokalnym „Broadwayem” i na której organizowano coś w rodzaju happeningów (np. stiladzy ustawiają się w rzędzie za niezauważającym ich przechodniem i naśladują jego ruchy, dopóki człowiek nie zorientuje się, że padł ofiarą żartu ${ }^{21}$. Stilagom przypisuje się też wykorzystywanie oryginalnej metody utrwalania muzyki na kliszach rentgenowskich, która przeszła do historii pod nazwami "muzyka na żebrach”, „muzyka na kościach”22. Ważnym elementem stylu bycia stilagów, podobnie jak

17 В. Петров, Страх, или жизнь в Стране Советов, Санкт-Петербург 2008, s. 22-23. Szczególną rolę w ośmieszaniu jazzu z pozycji, miłego władzy radzieckiej, autorytetu odegrał Maksim Gorki, publikując 18 kwietnia 1928 r. na łamach „Prawdy” artykuł o znamiennym tytule O muzyce tłustych (tj. kapitalistycznych obżartuchów).

18 Ibidem, s. 23. „Imprezy taneczne były przedsięwzięciami komercyjnymi - przynosiły jedyny dochód dyrektorom klubów, pałaców i domów kultury. A młodzież można było przyciągnąć tylko zakazanym fokstrotem. I szefowie tych instytucji starali się zdobyć u swojego partyjnego kierownictwa zezwolenie na jak największy procent ideologicznie szkodliwych tańców. Nie każdemu się to udawało". To oraz pozostałe tłumaczenia zostały dokonane przez autorkę, o ile nie zaznaczono inaczej.

19 „Farcowszczik” - od zniekształconego for sale (na sprzedaż); oznaczało spekulanta handlującego odkupionymi od zagranicznego turysty lub osoby powracającej z Zachodu rzeczami, głównie odzieżą, drobnymi gadżetami i płytami z muzyką.

20 Ciekawych informacji o życiu codziennym stilagów dostarcza autobiografia rosyjskiego saksofonisty Aleksieja Kozłowa, więcej zob. А. Козлов, Козел на саксе, Москва 1998, Электронная библиотека RoyalLib.com, https://royallib.com/book/kozlov_aleksey/kozel_na_sakse.html (dostęp: 22.10.2018).

21 V. Tarnavskyi, op. cit., s. 106.

22 S.F. Starr, Red and Hot. The Fate of Jazz in the Soviet Union, New York 1994, s. 240; Н. Шліхта, op. cit., s. 173. 
innych subkultur pokolenia '52, pozostawało szerokie stosowanie anglicyzmów w codziennej komunikacji ${ }^{23}$. Wreszcie stiladzy demonstracyjnie obnosili się z brakiem zainteresowania otaczającą ich rzeczywistością polityczno-społeczną. Nie zajmowała ich powojenna odbudowa i nie godzili się na wpisane w nią ascetyzm oraz wyrzeczenia konsumpcyjne. Ale tak samo nie interesowali się dążeniem do zmiany funkcjonującego porządku: $\mathrm{z}$ zachodnich stacji radiowych czerpali tylko muzykę, z książek i gazet wiedzę o kulturze i sztuce (nierzadko bardzo bogatą), ale bez inspiracji politycznych. Jak pisze ukraińska historyk Natalia Szlichta, formą protestu stilagów był eskapizm (warto dodać, że hedonistyczny) - próba zbudowania swojego zamkniętego świata bez nastawienia na przebudowę zastanych, niesatysfakcjonujących ich realiów ${ }^{24}$.

Ruch stilagów podlegał szerokiej krytyce. Uprawiano ją przede wszystkim na łamach prasy, takiej jak: „Prawda”, „Izwiestija”, „Krokodił” czy „Literaturnaja gazieta”, pisząc o stilagach w kontekście społecznego pasożytnictwa i chuligaństwa, a także proamerykańskiego szpiegostwa. Najpopularniejsze bodaj hasło: „Сегодня ты играешь джаз, а завтра Родину продашь!” („Dzisiaj tańczysz jazz, a jutro zdradzisz Ojczyznę!”) miało, jak się wydaje, nie tylko wyśmiewać nieprzyjęty w ZSRR styl bycia, ale i ostrzegać przed ewentualną pokusą zbliżenia do niego. Częstą wymierzoną w stilagów formą krytyki był rysunek satyryczny, na którym akcentowano rozwiązłość, przywiązanie do używek czy homoseksualizm jako nieodłączne cechy przypisywane młodym fanom jazzu. Do walki ze stilagami angażowano Komunistyczny Związek Młodzieży (Komsomoł), którego patrolom powierzano zadania wykrywania imprez stilagów oraz publiczne upokarzanie ich poprzez bicie, niszczenie odzieży i obcinanie włosów. Taka akcja nierzadko kończyła się po prostu ograbieniem stilagi. Za bycie stilagą można było zostać usuniętym ze szkoły, akademika bądź Komsomołu (ewentualnie zostać poddanym publicznemu osądowi na zebraniu komsomolskim), a wreszcie wysłanym na reedukację poprzez pracę na prowincję ${ }^{25}$.

Рисковали. Ведь грань между удовольствием купить себе костюм и сесть на год в тюрьму была очень тонкой. Комсомольский патруль - первое, что вас ожидало. Вы идете с девушкой, к вам подлетают и располосоввывают вам брюки. Или обстригают волосы. После того как вышел фильм Тарзан, все завели себе длинные прически, Ну, на них и накидывались с ножницами, резали волосы. И галстуки отрезали. Как-то все неумно делалось. Вышибали из ниститутов (Олег Яцкевич) ${ }^{26}$.

${ }^{23}$ S.F. Starr, op. cit., s. 238.

${ }^{24}$ Н. Шліхта, op. cit., s. 173.

25 S.F. Starr, op. cit., s. 237.

26 С. Трофимов, Я не лягу под стилягу или как в СССР боролись с подражателями Западу, Вестник. Информационно-политический портал, 25.08.2015, http://webdiscover.ru/v/240936 (dostęp: 14.06.2016). „Ryzykowaliśmy. Przecież granica między przyjemnością kupienia sobie nowego garnituru a pójściem na rok do więzienia była cienka. Komsomolski patrol to pierwsze co cię czeka. Idziesz z dziewczyną, a oni podlatują i rozcinają ci spodnie. Albo obcinają ci 
Generalnie jednak wysoki status rodziców stilagów był czynnikiem, który dość skutecznie niwelował surowość kary. Nietrudno także oprzeć się wrażeniu, że im więcej czasu upływało od śmierci Stalina oraz im dalej od centrum pojawiały się grupy stilagów, tym rzadziej i łagodniej ich karano. Rosyjska historyk Swietłana Rafikowa przywołuje nawet sytuację z Krasnojarska, w której to komsomolec za nieodpowiednie potraktowanie stilagi został pozbawiony wolności ${ }^{27}$. Początek końca ruchu stilagów wiązał się z utratą elitarności, jaką cieszyła się ta subkultura na początku lat pięćdziesiątych. Zadecydowały o niej odwilż zapoczątkowana na XX Zjeździe Komunistycznej Partii Związku Radzieckiego w lutym 1956 r. oraz VI Światowy Festiwal Młodzieży, który odbył się w Moskwie w 1957 r. Wtedy władze radzieckie częściowo zliberalizowały politykę kulturalną wobec muzyki jazzowej, zaś goszczący na festiwalu przedstawiciele Zachodu rozczarowali stilagów niedostatkiem przypisywanej im egzotyki ${ }^{28}$. Ruch stilagów uległ erozji, pojawiły się mniejsze grupy (np. sztatników - zainteresowanych stricte Stanami Zjednoczonymi czy firmienników - pasjonujących się kolekcjonowaniem markowej odzieży). Odwilż usankcjonowała wiele zjawisk kulturalnych, jeśli nie w oficjalnym, to przynajmniej w akceptowalnym w ZSRR obiegu publicznym.

\section{Filmowy stilaga}

W 2008 r. na ekrany rosyjskich kin wszedł film (musical) Stiladzy w reżyserii, urodzonego w Odessie, Walerego Todorowskiego. Główne role zagrali w nim aktorzy młodego pokolenia: Oksana Akińszyna i Anton Szagin, ale obsadę aktorską wydatnie wzmocniły znane talenty rosyjskiej i ukraińskiej kinematografii: Siergiej Garmasz i Ołeksiej Gorbunow. Trzon fabuły tworzy historia miłości Melsa - młodego komsomolca wychowywanego przez doświadczonego życiowo, tolerancyjnego i kochającego ojca oraz Poliny - stilażki, stałej bywalczyni moskiewskiego „Broadwayu”. Ich znajomość rozpoczyna się od interwencji komsomolskiego patrolu, której celem było rozgromienie nieudolnie ukrytej imprezy stilagów. Złapana przez Melsa Polina, w obawie przed szykanowaniem, kokietuje go i zaprasza na spotkanie. Chłopak przełamuje swój opór, przychodzi na „Broadway”, stopniowo poznaje świat nieznanej subkultury, znajduje nowych przyjaciół, zakochuje się w Polinie i rozpoczyna „nowe życie”.

włosy. Po tym jak wyszedł film Tarzan wszyscy zapuścili długie fryzury. Ale na nich rzucano się z nożyczkami, obcinano włosy. Obcinali też krawaty. Wszystko jakoś tak niemądrze się odbywało. Wyrzucali ze studiów" (Oleg Jackiewicz).

27 С. Рафикова, Сибирский стиляга, „Родина” (2010), № 9, http://archive.ec/oh5I (dostęp: 14.06.2016). Aleksandra Matyukhina pisze o represjach, aresztowaniach i zsyłkach w kontekście działań radzieckiego aparatu państwowego wobec „nieortodoksyjnych środowisk młodych ludzi”, nie konkretyzuje jednak tej informacji. Zob. A. Matyukhina, op. cit., s. 98.

28 S.F. Starr, op. cit., s. 248-251; Н. Шліхта, op. cit., s. 173-174. 
Akcja filmu rozgrywa się w końcówce czasów stalinowskich (1955-1956) ${ }^{29}$. Jest to okres, w którym na mocy amnestii z 1953 r. wychodzi na wolność tysiące byłych więźniów GUŁagu, chociaż wielki przełom polityczny jeszcze nie nastąpił. Starsze pokolenie w dużym stopniu żyje traumą terroru i obawia się, że każda jednostka może wciąż paść jego ofiarą. Z kolei w młodym pokoleniu zarysowują się już postawy odwilżowe, co tworzy też płaszczyznę dla konfliktu pokoleniowego ${ }^{30}$. Mimo że film jest utrzymany raczej w lekkiej, humorystycznej formie, realia epoki zostały wyraźnie zaakcentowane. Filmowi stiladzy w zdecydowanej większości wywodzą się z rodzin nomenklatury partyjnej i inteligencji. Ich rodzinny status umożliwia im $\mathrm{w}$ miarę bezproblemowe funkcjonowanie $\mathrm{w}$ przestrzeni publicznej Moskwy. Jeden z głównych bohaterów to syn ministra spraw zagranicznych, dzięki protekcji ojca może pozwolić sobie i swoim kolegom na wejścia do klubów przeznaczonych wyłącznie dla zagranicznych turystów, w przypadku problemów z milicją ratuje się telefonem do taty, a ostatecznie zostaje „za karę” wysłany na staż dyplomatyczny do USA ${ }^{31}$. Dzieci klasy robotniczej praktycznie nie mają dostępu do subkultury. Ci, którzy podejmują taka próbę, zmuszeni zostają do pokonania nie tylko barier materialnych, ale i ideologicznych. Autorytet instytucji Komsomołu

29 Osadzenie fabuły w tych właśnie latach nie wydaje się kwestią przypadku. Jak wskazałam wyżej, była to schyłkowa faza ruchu stilagów. Jednocześnie właśnie wtedy w prasie pojawiła się oficjalna krytyka zjawiska, np. karykatury stilagów w czasopiśmie „Krokodił” publikowano dopiero od połowy lat pięćdziesiątych. Była to typowa radziecka strategia polegająca na publicznym potępianiu problematycznej dla władz kwestii dopiero wtedy, kiedy traciła na znaczeniu albo została całkowicie opanowana.

${ }^{30}$ Więcej zob. O. Figes, Szepty. Życie w stalinowskiej Rosji, tłum. W. Jeżewski, Warszawa 2008, s. $425,454-503$.

31 Wątek rodzinnych konotacji prowadzi do refleksji nad stalinowską wizją rodziny. W latach trzydziestych władze odstąpiły od rewolucyjnej polityki dezawuowania rodziny i uznały ją za ważny czynnik stabilizacji porządku społecznego zagrożonego rozległą przestępczość nieletnich (problem tzw. bezprizornych i beznadzornych dzieci) - rodzina $\mathrm{z}$ dwojgiem rodziców miała ponownie podjąć zadania wychowawcze. Jednocześnie jednak rodzina nie była ani inicjatywą prywatną, ani źródłem osobistego spełnienia, uzasadniało ją bowiem służenie potrzebom państwa socjalistycznego, W.Z. Goldman, Women, the State and Revolution: Soviet Family Policy and Social Life, 1917-1936, Cambridge 1993, s. 296-343; F. Stella, Lesbian Lives in Soviet and Post-Soviet Russia, Basingstoke 2015, s. 28-29. Rodzina miała funkcjonować jako podstawowa komórka organizacyjna społeczeństwa, a lojalność poszczególnych jej członków wobec kolektywu i państwa winna mieć pierwszeństwo przed lojalnością wynikającą z pokrewieństwa (literacki przykład Pawlika Morozowa albo Wiaczesława Mołotowa rozwodzącego się z żoną na rozkaz Stalina i wiele innych tragedii rodzinnych w czasach wielkiego terroru). W filmie Stiladzy z jednej strony widzimy w pewnym sensie spełnianie pożądanej przez państwo roli wychowawczej rodzice Freda (minister z żoną) i Boba (lekarze) są przeciwni angażowaniu się dzieci w subkulturę, $\mathrm{z}$ drugiej strony ich postawa wynika $\mathrm{z}$ konformizmu i strachu, a nie $\mathrm{z}$ wierności ideologii. Fred nie zostaje ukarany przez rodziców zgodnie z teoretycznie obowiązującymi ich pryncypiami, ale w „korupcyjny” sposób odwiedziony od udziału w subkulturze, a jego dalsza kariera jest wsparta protekcją rodziców. Film pokazuje podwójne standardy moralne (zwłaszcza elity), ale i zrozumiały ludzki konformizm wynikający z siły więzi rodzinnych i każący dostosowywać się do obowiązujących reguł, lecz nie spełniać ich literalnie. 
jest wśród młodzieży robotniczej ogromny i ma niemal stuprocentowy wpływ na kształtowanie ich światopoglądu. Atmosferę społeczną stolicy ZSRR cechują strach przed donosicielstwem, szpiegostwem i zesłaniem oraz obyczajowy purytanizm. W domu lekarza pochodzenia żydowskiego stoi przygotowana „na wszelki wypadek" walizka z rzeczami osobistymi, które można zabrać do aresztu. Oryginalny ubiór i ekscentryczne zachowanie podlegają ostracyzmowi. Nie ma już śladu po rewolucji seksualnej lat dwudziestych: pozamałżeńska ciąża Poliny jest powodem, dla którego matka wyrzuca ją z domu. Ojciec Melsa - przedstawiciel klasy robotniczej i weteran wojenny, akceptujący młodzieńcze eksperymenty syna i jego nieformalny związek ze stilażką, która w dodatku rodzi czarne dziecko - jest po prostu społecznym dziwolągiem. Biografie filmowych bohaterów, dystansujących się od polityki jako takiej (nawet ambicje Melsa i jego przyjaciół z Komsomołu nie wykraczają poza tę organizację), pozostają mocno zdeterminowane przez kontekst polityczny swoich czasów.

W produkcji Todorowskiego można wyróżnić dwie sceny programowe, które konstytuują przekaz narracji filmowej. Pierwsza z nich to ta, w której Mels, pragnący zaimponować Polinie, prosi, a właściwie zmusza jednego z jej przyjaciół Boba, aby ten udzielił mu lekcji boogie-woogie. Scena służy unaocznieniu fascynacji zachodnią muzyką i stylem tańca, które były w ZSRR nie tylko niepopularne, ale i uznane za przejaw zepsucia, rozwiązłości itd. Ponadto pokazuje, że odmienność stylu bycia stilagów polegała na szeroko pojętej swobodzie, także tej wyrażanej rytmicznym, ale improwizowanym ruchem, w którym (w przeciwieństwie do propagowanego w ZSRR modelu uprawiania sportu) nie ma miejsca na rywalizację i wysiłek. Taniec jest tu symbolem wolności, przyjemności i aktywnego relaksu, tj. kategorii konsekwentnie pomijanych $\mathrm{w}$ radzieckim dyskursie publicznym lat pięćdziesiątych. Druga scena programowa to rozmowa Melsa (już po ewolucji tożsamościowej), który jako stilaga próbuje wytłumaczyć swojej byłej zwierzchniczce z Komsomołu, Katii, na czym polega istota subkultury stilagów. W swoim monologu koncentruje się na próbie wyjaśnienia znaczenia indywidualizmu jako wartości, stara się przekonać dawną koleżankę, że inność nie przekłada się w prosty sposób na zło, a akceptacja odmienności pozwala poszerzyć horyzonty myślowe.

Film Stiladzy jest niezwykle barwny, miły dla oka, przepełniony dobrą muzyką i atrakcyjną choreografią. Nie pozostaje jednak wolny od pewnych anachronizmów. Rzeczywistość przedstawiona w filmie (zarówno świat stilagów, jak i realia życia klasy robotniczej w Moskwie) została znacznie wyidealizowana. Stolica ZSRR to czysta i zadbana metropolia, a miejsca takie jak wielorodzinne mieszkanie w komunałce czy czarny rynek są raczej oryginalne i interesujące aniżeli odrażające i niebezpieczne. Szczególnie przejaskrawione zostały ubiory stilagów oraz łatwość, z jaką członkowie subkultury wchodzą w ich posiadanie. W rzeczywistości stilaga dysponował znacznie skromniejszym strojem i kompletował go nie bez ryzyka. Prywatne szycie ubrań tego typu, choć atrakcyjne dla krawców pod względem zarobkowym, porównywane było do spekulacji i podlegało karze nawet do 10 lat 
więzienia. $\mathrm{W}$ anonimowych wspomnieniach pracownicy zakładu krawieckiego w Krasnojarsku znajdujemy taki opis:

Я в 1951 году переехала в Красноярск, где и работала в ателье... Среди заказов были и такие, которые не совсем соответствовали образцу порядочного гражданина. Одной из таких заказчиц была девушка, звали её Рената Е. Являлась она, что ни есть стиляжкой-девушкой, или как заведено у них - чувихой. Родом она из обеспеченной семьи, отец врач, мать инженер, но видимо ей не хватало экстрима что ли? Наше знакомство устроила женщина, которая работала со мной же. Рената к ней пришла с просьбой о пошиве нарядов, та отказалась из-за боязни, что всё узнается и её могут арестовать. Пошив стиляжных вещей был запрещён, ведь стиль не соответствовал нашему устрою. Я, будучи провинциальной девушкой, согласилась, так как за работу предлагался большой для того времени заработок. Если обычный костюм стоил около 80-100 рублей, то стиляжный заказ стоил больше ста рублей, и прибыль шла именно мастеру. Занималась я пошивом подпольно, шила Ренате у себя на дому ${ }^{32}$.

Innym zauważalnym w filmie anachronizmem jest muzyka. Musical Todorowskiego oparty został nie na jazzie z lat pięćdziesiątych, ale na hitach (z zachowaną linią melodyczną, zmienionymi lub uzupełnionymi słowami, czasami zmodyfikowaną aranżacją) radzieckich zespołów rockowych popularnych w epoce Leonida Breżniewa: Brawo, Maszyna Wriemieni, Kino, Zoopark, Nol', Kolibri, Nautilus Pompilius. Odpowiada to nie tyle czasom samych stilagów, ile trendowi zainteresowania subkulturą, jaki pojawił się w radzieckim rocku w latach osiemdziesiątych:

Где твои туфли на „манной каше”?

И куда ты засунул свой двубортный пиджак?

Спрячь подальше домашние тапки, папаша!

Ты ведь раньше не дал бы за них и пятак! ${ }^{33}$

32 Стиляги в СССР, Летопись. Новости археологии и истории, 19.07.2013, http://oursociety.ru/ publ/istorija_rossii/stiljagi_v_sssr/4-1-0-176 (dostęp: 22.10.2018). „W 1951 roku przyjechałam do Krasnojarska, gdzie pracowałam w zakładzie krawieckim. Wśród zamówień, które otrzymywaliśmy trafiały się i takie, które nie były w pełni stosowne dla przyzwoitego obywatela. Jedne z takich zamówień składała Renata E., stilażka, czy jak to było przyjęte u nich - czuwicha. Pochodziła z dobrze usytuowanej rodziny, ojciec lekarz, matka inżynier, ale widocznie chyba brakowało jej jakiegoś ekstremum? Poznała nas ze sobą kobieta, która też u nas pracowała. To do niej Renata zwróciła się z prośbą o uszycie stroju, ale ta odmówiła, ponieważ bała się, że wszystko się wyda i zostanie aresztowana. Szycie strojów dla stilagów było zabronione, bo przecież ich styl nie był zgodny z naszym ustrojem. Ja pochodziłam z prowincji i zgodziłam się szyć, ponieważ za tę pracę można było uzyskać znaczny, jak na tamte czasy, zarobek. Jeśli zwykły kostium kosztował około 80-100 rubli, to zamówienie stilagi więcej niż sto i cały dochód trafiał się wykonawcy. Szyłam więc Renacie na czarno, u siebie w domu".

33 Zespół Kino, utwór Kiedyś byłeś bitnikiem, ros. Когда-то ты был битником, https://www. youtube.com/watch?v=3PH2IvQzUwg (dostęp: 20.10.2018). „Gdzie są Twoje buty na «kaszy mannie»? / I gdzie schowałeś swoją dwurzędową marynarkę? / Schowaj jak najdalej domowe kapcie! / Przecież dawniej nie dałbyś za nie piątaka!” 
Спросите у любого на Тверском бульваре,

Кто лучше всех танцует твист и рок-н-ролл,

Кто лучше всех играет Пресли на гитаре,

На это каждый ответит, каждый ответит:

- Конечно, Вася, Вася, Вася!

Ну кто его не знает,

Вася, Вася, Вася, стиляга из Москвы ${ }^{34}$.

Film ukazuje ruch stilagów w pewnym ciągu kulturowym: jako kontynuatorów jazzmanów $\mathrm{z}$ lat dwudziestych i jednocześnie prekursorów później obecnych w ZSRR subkultur: hipisów, punków, rastafarianów i innych. Potwierdza, że subkulturę tę tworzyły głównie dzieci nomenklatury, elity artystycznej i inteligencji, a także to, że właśnie status społeczny pozwalał skutecznie niwelować ostracyzm, a nierzadko wpływał na uniknięcie czy złagodzenie kary. Swoje odzwierciedlenie w filmie znajdują również apolityczność i bezprogramowość ruchu stilagów, którzy godzili w system jedynie (a może aż) ostentacyjnym obnoszeniem się z innością i brakiem entuzjazmu dla wyzwań partii, dotyczących budowy komunizmu. Film sygnalizuje również, że poza szerzoną przez propagandę pogardą dla stilagów, budzili oni w reszcie społeczeństwa (przynajmniej w części) zainteresowanie, a nawet zazdrość. Adekwatność tego przekazu potwierdza materiał badawczy zebrany przez Rafikową na Syberii: „В школе их ругали, а мы, с одной стороны, и подсмеивались, а с другой - завидовали. [...] К стилягам муж относился скептически, критиковал слегка. А я им немного завидовала: хотелось одеваться так же модно" 35 .

Jest to dobry punkt wyjścia dyskusji na temat szerszej zmiany społecznej w ZSRR, w ramach której postawa człowieka radzieckiego ewoluowała od ascetycznego rewolucjonisty, gotowego w imię świetlanej przyszłości żyć w spartańskich warunkach, do człowieka żyjącego "tu i teraz", konsumenta nie tylko szerokiego asortymentu dóbr, ale i czasu.

\section{Dyskusja nad fenomenem stilagów we współczesnej Rosji}

Film Todorowskiego z pewnością przyczynił się do ożywienia zauważalnego w Rosji i wpasowującego się w pewną ogólnoświatową tendencję nostalgicznego zainteresowania latami pięćdziesiątymi na poziomie kultury popularnej i estetyki. Po jego wyemitowaniu pojawiła się swego rodzaju moda na imprezy korporacyjne,

${ }^{34}$ Zespół Brawo, utwór Wasia, ros. Bacя, https://www.youtube.com/watch?v=43RDuxe7CzM (dostęp: 20.10.2018). „Zapytajcie przechodnia na Twerskim bulwarze, / Kto najlepiej tańczy twista i rock and rolla, / Kto najlepiej gra Presley'a na gitarze, / Każdy odpowie, każdy odpowie: / Oczywiście, Wasia, Wasia, Wasia! / Kto by go nie znał, / Wasia, Wasia, Wasia, stilaga z Moskwy!”

35 С. Рафикова, op. cit. „W szkole im wymyślano, a my z jednej strony podśmiechiwaliśmy, a z drugiej - zazdrościli. [...] Mąż sceptycznie odnosił się do stilagów. Krytykował nieco. A ja im troszkę zazdrościłam: też chciałam tak modnie się ubierać”. 
bale maturalne, a nawet wesela w stylu stilagów. Film został też doceniony przez rosyjskie środowisko filmowe, zebrał wiele nagród, $\mathrm{w}$ tym prestiżową nagrodę rosyjskiej kinematografii „Nika” (2009) za najlepszy film fabularny. I wreszcie, za jego sprawą, we współczesnym rosyjskim dyskursie publicznym pojawiło się pytanie o złożoność życia codziennego w ZSRR. Przypomniani przez Todorowskiego stiladzy stali się przedmiotem dyskusji: czy jako produkt kultury radzieckiej reprezentowali światłą, postępową, protodysydencką część społeczeństwa, czy raczej zdegenerowaną „bananową młodzież”? Odzwierciedlenie tej skrajności w postrzeganiu fenomenu stilagów znalazło swój wyraz w krytycznej wypowiedzi rosyjskiego pisarza Aleksieja Kabakowa. Jego zdaniem w filmie zachodzi nieuprawniona idealizacja epoki radzieckiej: kary i szykany, które spotykają stilagów są nieadekwatne do historycznej rzeczywistości. Ruch stilagów, autentycznych kontestatorów, został przybliżony widzowi z perspektywy wesolutkiej komedyjki. „Чуваки и чувихи так их называли в пятидесятых годах, а не стиляги - подвергались чудовищному преследованию государства. Над ними измывались и, прямо скажем, с точки зрения режима издевались вполне заслуженно. Они действительно были врагами советской власти - сознательными и упорными, это первые и совершенно органические диссиденты" 36.

Równie krytyczna, choć z zupełnie inną argumentacją, okazała się recenzja opublikowana na stronie internetowej petersburskiego oddziału Komunistycznej Partii Federacji Rosyjskiej. Zarzucono w niej, że Stiladzy prezentują niesłusznie zmitologizowany obraz dzieci partyjnej wierchuszki, którym „w głowach się poprzewracało" od braku obowiązków i odpowiedzialności. Film został odebrany jako „czarno-biały”, zogniskowany na utrwaleniu w młodym pokoleniu Rosjan kontry pomiędzy dobrym, prozachodnim stilagą i zahukanym „sowkiem”. „Здесь зомбированые тупые «советские люди» особенно сильно отличаются от свободомыслящих и интеллигентных тусовщиков с «Бродвея»"37.

Przywołane wyżej recenzje powstały w środowiskach inteligencji. Ich autorzy zdawali się oczekiwać od filmu publicznego i kategorycznego usankcjonowania postulowanych przez nich historycznych wizji fenomenu subkultury z czasów stalinowskich. W zaciętej krytyce Todorowskiego umknął im fakt, że Stiladzy nie zostali

36 Я. Колесинская, Александр Кабаков: Хочу тиражи, как у Минаева, но быть как Минаев - увольте, Сибкрай.ru, 29.04.2009, http://sibkray.ru/news/54/21952/ (dostęp: 22.10.2018). „Czuwaki i czuwichy - tak, a nie stilagami, nazywano ich naprawdę w latach pięćdziesiątych - poddani byli potwornemu prześladowaniu ze strony państwa. Znęcano się nad nimi, ale szczerze mówiąc, z punktu widzenia reżimu znęcano się w pełni zasłużenie. Oni naprawdę byli wrogami władzy radzieckiej - świadomymi i upartymi, to pierwsi organiczni wręcz dysydenci”.

37 Т. Краснов, „Стиляги”. Рецензия на очередную антисоветскую киноподелку, Коммунистическая Партия Российской Федерайии Петерсбурское отделение, 05.01.2009, http://www. cprfspb.ru/1027.html (dostęp: 22.10.2018). Зомбированье („zzombieni”) - podobni do zombie, tj. zachowujący się jak żywe trupy niekierujące się wolną wolą, ogłupione przez propagandę. „Tutaj zzombieni tępi «ludzie sowieccy» szczególnie mocno odróżniają się od swobodnie myślących i inteligentnych bywalców «Broadwayu»". 
pomyślani jako dokument i że przyjęta przez reżysera musicalowa forma rządzi się swoim prawem pierwszoplanowego eksponowania muzyki i tańca. W moim przekonaniu wartość obrazu stworzonego przez Walerego Todorowskiego polega na samym wprowadzeniu do współczesnej rosyjskiej kultury popularnej relatywnie słabo zbadanego wątku stilagów, co inspiruje do dyskusji o różnorodnych obliczach życia codziennego w ZSRR.

Polemika na temat roli stilagów w ZSRR ma wyjątkowo elitarny charakter, $\mathrm{w}$ zasadzie od dawna toczy się w gronie akademickim oraz wśród inteligencji artystycznej ${ }^{38}$. Współcześnie na poziomie „reprezentacyjno-popularyzatorskim” próbuje się natomiast dokonać włączenia fenomenu stilagów w historiografię narodową. Spektakularnym przykładem była ceremonia otwarcia Zimowych Igrzysk Olimpijskich w Soczi w 2014 r. Przedstawiono tam widowisko historyczne poświęcone dziejom Rosji od wczesnego średniowiecza do współczesności, w którym na etapie lat pięćdziesiątych zaprezentowano nieskrępowany taniec uliczny wykonany przez grupę ekstrawagancko ubranej młodzieży w obecności niereagującej milicji ${ }^{39}$. Nie sposób oprzeć się wrażeniu, iż miało to służyć kreowaniu nowego, eksportowego wizerunku Rosji, która chce przekonać młode pokolenie na Zachodzie, że także ma „kolorowe” karty swojej historii. Strategia wykorzystania motywu stilagów $\mathrm{w}$ charakterze chwytu marketingowego mającego promować turystykę do Rosji została również wykorzystana na stronach internetowych Rosyjskiego Narodowego Biura Turystycznego w Wielkiej Brytanii. Znajdziemy tam notkę przybliżającą potencjalnemu brytyjskiemu turyście stilagów jako radzieckich odpowiedników teddy boys - działających jednak w o wiele trudniejszych warunkach i sprzeciwiających się aparatowi opresyjnego państwa w imię prawa jednostki do wolności. Jest to jednak tylko coś w rodzaju historycznej ciekawostki, bo jak przekonują autorzy strony: „Russia has changed immensely since the rebellious days of the stilyagi. Today, you can dress as you want and listen to whatever music you choose. There are a huge amount of events and concerts, bars and clubs where you can enjoy every type of music. So why not book a trip to Russia today. Just visit the website or call us [...]. And don't forget your dancing shoes!"40.

38 Zob. nр.: Л. Ионин, Социология культуры, Москва 2004, s. 116; В. Славкин, Взрослая дочь молодого человека: Пьеса, Москва 1979; idem, Памятник неизвестному стиляге: История поколения в анекдотах, легендах, байках, песнях, Москва 1996.

39 The Complete Sochi 2014 Opening Ceremony, YouTube.pl, 03.02.2018, https://www.youtube.com/ watch? $\mathrm{v}=$ bKhuvril8Rs (dostęp: 22.10.201).

40 Meet the „stilyagi”, Visit. Russia. Russian National Tourist Office, 24.11.2014, https://www.visitrussia.org.uk/blog/meet-the-stilyagi/ (dostęp: 23.10.2018). Spostrzeżenie to zawdzięczam mojej studentce z Instytutu Wschodniego Uniwersytetu im. A. Mickiewicza w Poznaniu - Ewelinie Kowalskiej. „Rosja ogromnie się zmieniła od czasów zbuntowanych stilagów. Dzisiaj możesz ubierać się jak chcesz i słuchać takiej muzyki, jaką sam wybierzesz. Jest tam całe mnóstwo imprez, koncertów, barów i klubów, gdzie można cieszyć się każdym rodzajem muzyki. A więc dlaczego nie zarezerwować wycieczki do Rosji już dziś. Odwiedź naszą stroną lub zadzwoń [...]. I nie zapomnij swoich tanecznych butów!” 


\section{Stilyagi - the Soviet Version of Generation '52 and its Image in Valery Todorovsky's Film Stilyagi}

\section{Abstract}

This article is devoted to the first Soviet subculture - the stilyagi, who appeared in the Soviet Union at the end of the 1940s. They were part of a wider, European phenomenon, the so-called "Generation ' 52 ", a wave of subcultures fascinated by the American way of life. They expressed their individuality, firstly, by wearing fashionable clothes (preferably of foreign label) and, secondly, by listening to forbidden jazz and passion for expressive dances. They demonstrated the hedonistic approach to life and total lack of commitment to the idea of building communism propagated by communist propaganda. Although they did not proclaim any political ideology and avoided political issues, they were fought against by the state authorities. The fight against the stilyagi movement, however, was relatively mild as for the Stalinist era. This resulted from the fact that its members came from the families of party nomenclature, intellectual and artistic elites.

The text presents a comparative analysis of the studies available in the literature on the subject with the image of the subculture presented in the popular film by Valery Todorovsky entitled Stilyagi. The main purpose of the analysis is to answer the question: to what extent the discussed film is a narrative history of the first Soviet movement contesting official cultural and entertainment standards, and not an attempt at its mythologization.

\section{Стиляги - советский вариант генерации '52 и ее образ в картине Стиляги Валерия Тодоровского}

\section{Аннотация}

Данная статья посвящена первой советской субкультуре - стилягам, которые появились в Советском Союзе рубеже 1940-х и 1950-х годов. Стиляги являлись частью более широкого, общеевропейского явления т.н. генерации'52, то есть волны субкультур, увлекавшихся американским образом жизни. Для них характерны были любовь к экстравагантной одежде, джазовой музыке, а также экспрессивному танцу. Они демонстрировали гедонистский подход к жизни и полное отсутствие вовлеченности в распространяемую пропагандой идею стройки коммунизма. Несмотря на то, что они не распространяли никакой политической программы и вообще держались в стороне от политики - власти с ними боролись.

Борьба с движением стиляг была, однако, сравнительно мягкая, для сталинских времен. Это было следствием того, оно чаще всего состояло из членов семей высокопоставленных партийных деятелей, интеллигенции и творческой элиты. В тексте были сравнены, доступные в литературе, исследования по стилягам с образом субкультуры, представленным в пользующимся большой популярностью в России, фильме Валерия Тодоровского Стиляги. Вывод стремится к ответу на вопрос: до какой степени, обсуждаемая картина является повестью, рассказывающей о первом в Советском Союзе движении, открыто оспаривающем официальные культурно-развлекательные стандарты, а насколько попыткой его мифологизации. 


\section{Bibliografia}

\section{Opracowania}

Chłopek M., Bikiniarze. Pierwsza polska subkultura, Warszawa 2005.

Fedorowicz A., Swing heil!, „Polityka” (21 IV 2015).

Figes O., Szepty. Życie w stalinowskiej Rosji, tłum. W. Jeżewski, Warszawa 2008.

Filipiak M., Od subkultury do kultury alternatywnej. Wprowadzenie do subkultur młodzieżowych, Lublin 1999.

Goldman W.Z., Women, the State and Revolution: Soviet Family Policy and Social Life, 19171936, Cambridge 1993.

Grunberger R., Historia społeczna Trzeciej Rzeszy, tłum. W. Kalinowski, t. 2, Warszawa 1987.

Matyukhina A., W sowieckim Lwowie. Życie codzienne miasta w latach 1944-1990, Kraków 2000.

Paleczny T., Kontestacja. Formy buntu we współczesnym społeczeństwie, Kraków 1997.

Pęczak M., Mały słownik subkultur młodzieżowych, Warszawa 1992.

Portis L., French Frenzies: A Social History of Pop Music in France, College Station 2004.

Starr S.F., Red and Hot. The Fate of Jazz in the Soviet Union, New York 1994.

Stella F., Lesbian Lives in Soviet and Post-Soviet Russia, Basingstoke 2015.

Szarota T., Życie codzienne w stolicach okupowanej Europy. Szkice historyczne. Kronika wydarzeń, Warszawa 1995.

Tarnavskyi V., Dzieci swoich czasów. Ruchy młodzieżowe w Rosji a zmiany kulturowe po upadku ZSRR, Warszawa 2007.

Thorne T., Mody, kulty, fascynacje. Słownik pojęć kultury postmodernistycznej, tłum. Z. Batko, Warszawa 1995.

Ионин Л., Социология культуры, Москва 2004.

Козлов А., Козел на саксе, Москва 1998, Электронная библиотека RoyalLib.com, https:// royallib.com/book/kozlov_aleksey/kozel_na_sakse.html (dostęp: 22.10.2018).

Колесинская Я., Александр Кабаков: Хочу тиражи, как у Минаева, но быть как Минаев - увольте, Сибкрай.ru, 29.04.2009, http://sibkray.ru/news/54/21952/ (dostęp: 22.10.2018).

Краснов Т., „Стиляги”. Рецензия на очередную антисоветскую киноподелку, Коммунистическая Партия Российской Федерайии Петерсбурское отделение, 05.01.2009, http:// www.cprfspb.ru/1027.html (dostęp: 22.10.2018).

Петров В., Страх, или жизнь в Стране Советов, Санкт-Петербург 2008.

Рафикова С., Сибирский стиляга, „Родина” (2010), № 9, http://archive.ec/oh5I (dostęp: 14.06.2016).

Славкин В., Взрослая дочь молодого человека: Пьеса, Москва 1979.

Славкин В., Памятник неизвестному стиляге: История поколения в анекдотах, легендах, байках, песнях, Москва 1996.

Стиляги в СССР, Летопись. Новости археологии и истории, 19.07.2013, http://oursociety. ru/publ/istorija_rossii/stiljagi_v_sssr/4-1-0-176 (dostęp: 22.10.2018).

Трофимов С., Я не лягу под стилягу или как в СССР боролись с подражателями Западу, Вестник. Информационно-политический портал, 25.08.2015, http://webdiscover. $\mathrm{ru} / \mathrm{v} / 240936$ (dostęp: 14.06.2016).

Шаповал В.В., Цыганские элементы в русском воровском арго? (размышления над статьей акад. А.П. Баранникова 1931 г.), „Вопросы языкознания” (2007), № 5, s. 108-128, Philology.ru - Русский филологический портал, http://www.philology.ru/linguistics2/ shapoval-07c.htm (dostęp: 23.10.2018).

Шліхта Н., Історія радянсього суспільства. Курс лекцій, Харків 2015. 
Marta Studenna-Skrukwa, dr, adiunkt w Instytucie Wschodnim Uniwersytetu im. A. Mickiewicza w Poznaniu. Zainteresowania badawcze: historia społeczna i historia życia codziennego w Związku Radzieckim, epoka Breżniewa, tożsamość regionalna pogranicza ukraińsko-rosyjskiego, historia najnowsza Ukrainy (studnia@amu.edu.pl).

Marta Studenna-Skrukwa, PhD, professor assistant at the Institute of Eastern Studies of the Adam Mickiewicz University in Poznań; her research interests are: social history and everyday life in the Soviet Union, Brezhnev era, regional identity of the Ukrainian-Russian borderland, modern history of Ukraine (studnia@amu.edu.pl). 